Crema, G. L., Bagni, B., and Biocalti, A. R. (1969). Minerva Radiologica Fistioterapica e Radiobiologica, 14, 484.

de Garreta, A. C., Glass, H. I., and Goolden, A. W. G. (1968). British fournal of Radiology, 41, 896.

Degrossi, O., Gotta, H., Olivari, A., Pecorini, V., and Chwojnik, A. (1965). Nuclear-Medizin, 4, 383.

Goolden, A. W. G. (1960). British Medical Bulletin, 16, 105.

Goolden, A. W. G., Glass, H. I., and Silvester, D. J. (1968). British fournal of Radiology, 41, 20.

Goolden, A. W. G., Glass, H. I., and Williams, E. D. (1971). British Medical fournal, 4, 396.

Haas, J. P., Schmidt, K. J., and Wolf, R. E. (1968). Fortschritte auf dem Gebiete der Röentgenstrahlen und der Nuklearmedizin, 109, 222.

Harper, P. V., Andros, G., and Lathrop, K. (1962). Argonne Cancer Research Hospital Semiannul Report to the Atomic Eneroy Commission 1962 No. 18, p. 76. Washington, D.C., Office of Technical Services, Department of Commerce.

Hauser, W., Atkins, H. L., Eckelman, W. C., and Richards, P. (1971). American Fournal of Roentgenology, Radium Therapy, and Nuclear
Hilditch, T. E., Gillespie, F. C., Shimmins, J., Harden, R. McG., and Alexander, W. D. (1967). Fournal of Nuclear Medicine, 8, 810

Hoschl, R., and Gimlette, T. M. D. (1971). Nuclear-Medizin, 10, 305

International Atomic Energy Agency (1962). Physics in Medicine and Biology, 6, 533.

Kuba, J., Knoll, P., Husak, V., Wiedermann, M., and Charamza, O. (1966). Fortschritte auf dem Gebiete der Roentgenstrahlen und der Nuklearmedizin, $105,84$. Kuba, J., Wiedermann, M., and Komenda, S. (1967). Nuclear-Medizin, 6,

McGill, P. E., Harden R. McG., Robertson, I. W. K., and Shimmins, J. (1971). Fournal of Endocrinology, 49, 531.

Shimmins, J. G., Hilditch, T., Harden, R. McG., and Alexander, W. D. (1968). Fournal of Clinical Endocrinology and Metabolism, 28, 575.

Shimmins, J. G., Harden, R. McG. and Alexander, W. D. (1969). Fournal of

Nuclear Medicine, 10, 637.
Umek, H., and Czembirek, H. (1968). Nuclear-Medizin, 7, 231.

Williams, E. D., Glass, H. I., Goolden, A. W. G., and Satyavanich, S. (1972). Fournal of Nuclear Medicine, 13, 159.

\title{
Ferritin in the Serum of Normal Subjects and Patients with Iron Deficiency and Iron Overload
}

\author{
A. JACOBS, F. MILLER, M. WORWOOD, M. R. BEAMISH, C. A. WARDROP
}

British Medical fournal, 1972, 4, 206-208

\section{Summary}

The concentration of ferritin in serum gives a quantitative measure of the amount of storage iron in normal subjects and those with iron deficiency or overload. The mean level in normal men is $69 \mathrm{ng} / \mathrm{ml}$, compared with $35 \mathrm{ng} / \mathrm{ml}$ in normal women. A concentration below $10 \mathrm{ng} / \mathrm{ml}$ is associated with a low transferrin saturation and iron-deficient erythropoiesis.

\section{Introduction}

Ferritin is found mainly in the cytoplasm of reticuloendothelial cells and liver cells. It is normally thought to be a storage compound from which iron is mobilized into the transferrinbound plasma pool. A little ferritin is present in developing red cell precursors in the bone marrow. It has not previously been thought to appear in the plasma or extracellular fluid under normal conditions (Reissman and Dietrich, 1956; Aungst, 1966). Recently, however, a sensitive immunoradiometric assay has been described which has resulted in the detection of ferritin in normal serum (Addison et al., 1972). Preliminary data on serum ferritin concentrations suggested that the level of circulating ferritin is related to body stores of iron and that the assay might provide a valuable method of screening subjects for subnormal or excessive storage levels.

This paper reports on serum concentrations in normal subjects, patients with iron deficiency anaemia, and patients with both primary and secondary iron overload.

\section{Subjects and Methods}

Normal Subjects.-Seventy-five unselected apparently healthy men aged between 18 and 65 years were examined. Blood samples were taken as part of a routine health screening

Welsh National School of Medicine, Cardiff

A. JACOBS, M.D., M.R.C.PATH., Professor of Haematology

F. MILLER, B.SC., Research Assistant

M. WORWOOOD, PH.D., Lecturer in Haematology

M. R. BEAMISH, M.B., M.R.C.PATH., Lecturer in Haematology

C. A. J. WARDROP, M.B., M.R.C.PATH., Senior Lecturer in Haematology procedure in a Cardiff factory. Forty-four apparently healthy women members of staff at Velindre Hospital, Cardiff, were examined at the time that routine blood samples were being taken for screening purposes. Haematological criteria are shown in the Table. No marrow examinations were carried out in this group.

Haematological Data in Normal and Iron-Deficient Subjects. (Mean \pm $S . E .$, range in parentheses)

\begin{tabular}{l|c|c|c|c}
\hline & $\begin{array}{c}\text { No. } \\
\text { of } \\
\text { Sub- } \\
\text { jects }\end{array}$ & $\begin{array}{c}\text { Haemoglobin } \\
(\mathrm{g} / 100 \mathrm{ml})\end{array}$ & $\begin{array}{c}\text { Serum Iron } \\
(\mu \mathrm{g} / 100 \mathrm{ml})\end{array}$ & $\begin{array}{c}\text { Transferrin } \\
\text { Saturation (\%) }\end{array}$ \\
\hline $\begin{array}{c}\text { Normal men } \\
\begin{array}{c}\text { Normal } \\
\text { women }\end{array}\end{array}$ & 75 & $15 \cdot 7 \pm 0 \cdot 1(13 \cdot 4-17 \cdot 5)$ & $123 \cdot 5 \pm 4 \cdot 8(44 \cdot 0-220 \cdot 0)$ & $30 \cdot 6 \pm 1 \cdot 3(9 \cdot 0-60 \cdot 0)$ \\
$\begin{array}{c}\text { Iron- } \\
\text { deficient } \\
\text { patients }\end{array}$ & 21 & $9 \cdot 1 \pm 0.3(5 \cdot 6-12 \cdot 6)$ & $20 \cdot 4 \pm 1 \cdot 7(10 \cdot 0-36 \cdot 0)$ & $4 \cdot 3 \pm 0.5(2 \cdot 0-11 \cdot 0)$ \\
\hline
\end{tabular}

Iron deficiency Anaemia.-Twenty-one adults (17 women and four men) with untreated iron-deficiency anaemia were examined. The haematological criteria are shown in the Table. Bone marrow fragments were obtained by aspiration, and neither smears nor histological sections showed the presence of stainable iron.

Primary Haemochromatosis.-Eight patients with haemochromatosis in whom the diagnostic criteria included excessive iron deposits in liver biopsy samples and a differential ferrioxamine test (Fielding, 1965) showing an increased amount of chelatable iron, $F_{v}$ varying between 1,072 and $3,303 \mu \mathrm{g}$ ferrioxamine/ $\mathrm{kg}$ body weight. The mean serum iron in this group was $246.5 \pm 23.1 \mathrm{mg} / 100 \mathrm{ml}$, and the mean transferrin saturation $88.3 \pm 4 \cdot 2 \%$.

Refractory Anaemia.-Thirteen patients with primary refractory anaemia, all but one of whom had been treated with blood transfusion. In a number of cases more than one sample was taken from the patient at widely differing times so that the effects of increase in iron load could be seen. A total of 24 samples were obtained. The mean haemoglobin concentration in this group was $8.9 \pm 0.6 \mathrm{~g} / 100 \mathrm{ml}$, mean serum iron $171.8 \pm 16.8 \mathrm{mg} / 100 \mathrm{ml}$, and the mean transferrin saturation $68 \cdot 1 \pm 6 \cdot 5 \%$. 
Haematological parameters were measured by using a Coulter $S$ automatic cell counter. Serum iron concentration was measured by the method of Young and Hicks (1965), and total iron binding capacity was measured using the same method with magnesium carbonate as an absorbent. Serum ferritin concentration was measured by using the immunoradiometric assay of Addison et al. (1972).

\section{Results}

Normal Subjects.-The serum ferritin concentration ranged from 6 to $186 \mathrm{ng} / \mathrm{ml}$ in men (mean $69 \cdot 2 \pm 5 \cdot 2$ ) and from 3 to $162 \mathrm{ng} / \mathrm{ml}$ in women (mean $34 \cdot 8 \pm 5 \cdot 1$ ). There is a skew distribution in both sexes as shown in Fig. 1. There is no correlation between serum ferritin concentration and transferrin saturation in men, though in women there is a significant correlation $(r=0.66, P<0.001)$. This difference may be partly related to the larger number of women with low

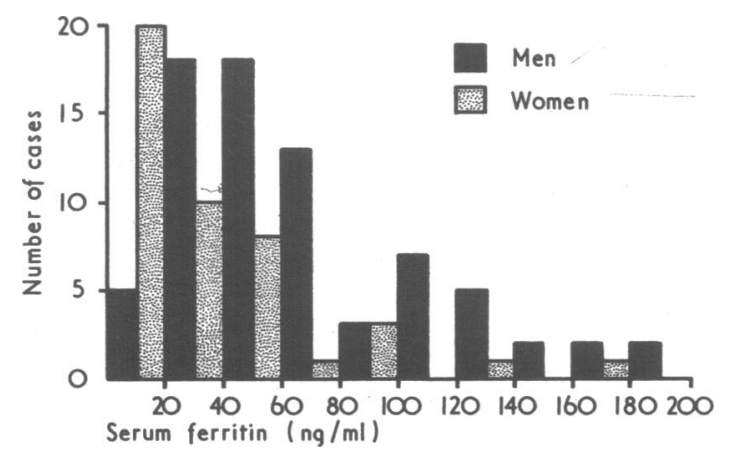

FIG. 1-Distribution of serum ferritin concentrations in normal men and women.

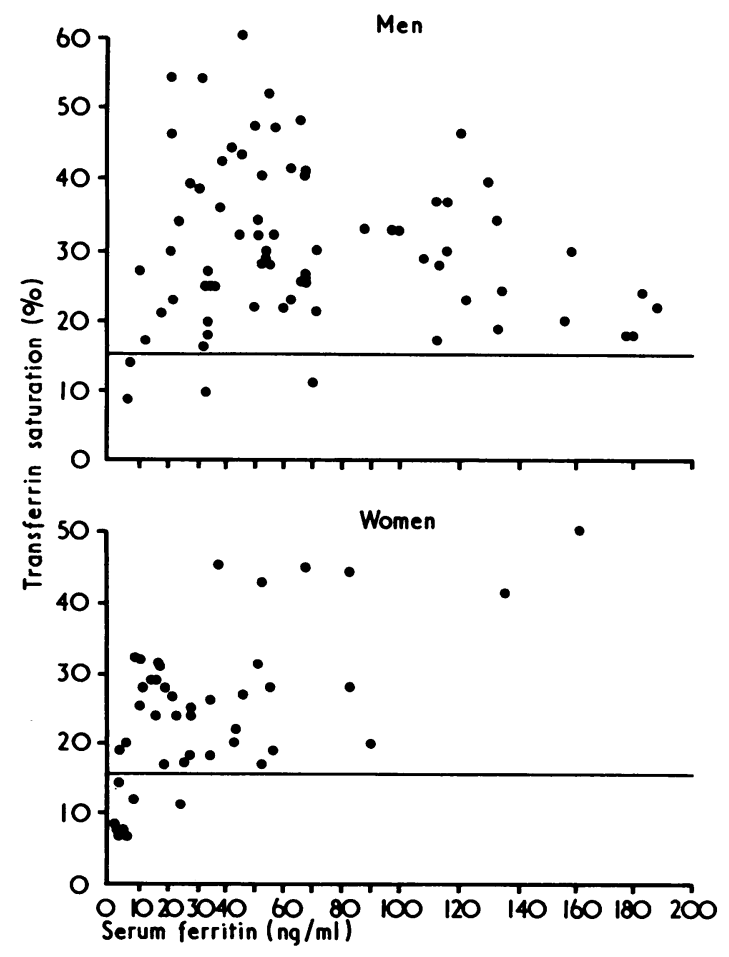

FIG. 2-Serum ferritin concentrations and transferrin saturation in normal men and women.

ferritin concentrations (Fig. 2). In both sexes a serum ferritin concentration below $10 \mathrm{ng} / 100 \mathrm{ml}$ is associated with a transferrin saturation of less than $16 \%$. In the two women where low serum ferritin concentrations are associated with transferrin saturations of 19 and $20 \%$ respectively, both were found on subsequent questioning to be taking iron tablets.
Iron-deficiency Anaemia.-Serum ferritin concentration in 21 cases were in the range $1-12 \mathrm{ng} / \mathrm{ml}$ (mean $5 \cdot 0 \pm 0.66$ ). This range is almost exactly that which in normal subjects is associated with a low transferrin saturation, and presumably indicates depleted body stores.

The Effect of Venesection.-Three normal men volunteered to have blood removed by repeated venesection. In all cases there was an immediate fall in circulating ferritin concentration though transferrin saturation remained normal until after the fourth venesection. In all cases when circulating ferritin concentration dropped below $10 \mathrm{ng} / \mathrm{ml}$ there was an associated fall in transferrin saturation to less than $16 \%$. The course of events in one such case is shown in Fig. 3. In this

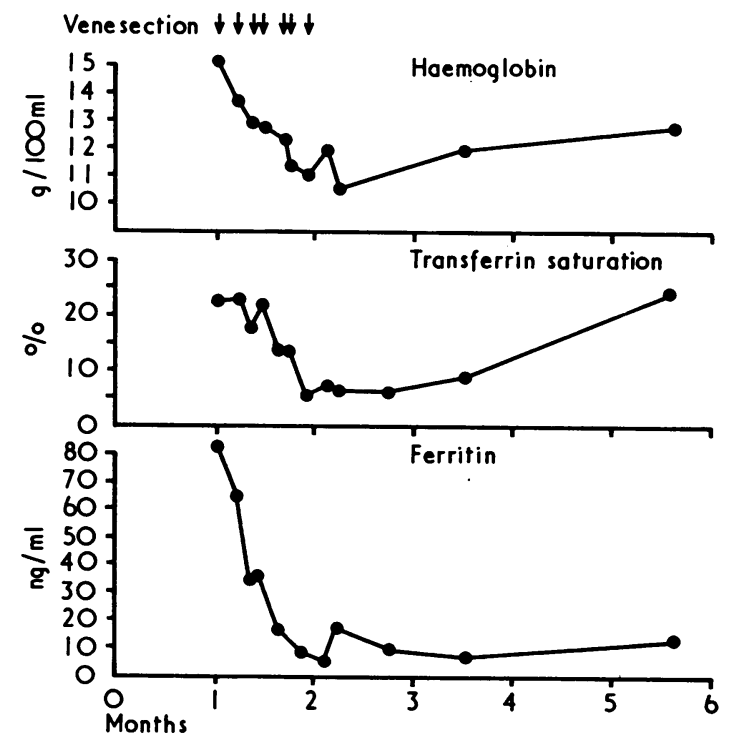

FIG. 3-Effect of repeated venesection in a normal man on haemoglobin concentration, transferrin saturation, and serum ferritin concentration. Three iron tablets were taken two days after last venesection.

instance recovery from the effects of venesection was prolonged; there was a gradual rise in haemoglobin over the subsequent months with a gradual return of transferrin saturation to normal levels. Circulating ferritin concentration remained low, however, though it eventually rose above $10 \mathrm{ng} /$ ml.

Refractory Anaemia.--The mean serum ferritin concentration in 24 samples taken from 13 patients with primary refractory anaemia was $1,790 \pm 266 \mathrm{ng} / \mathrm{ml}$. There is a close correlation between the serum ferritin concentration and the iron load induced by transfusion therapy (Fig. 4) $(r=0.9$, $\mathbf{P}<0.001$ ).

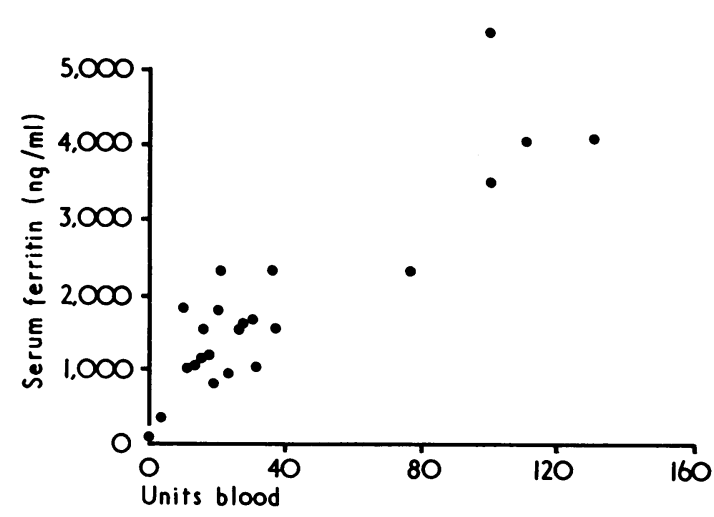

FIG. 4-Relation between number of units of blood transfused and serum ferritin concentration in patients with refractory anaemia. 
Primary Haemochromatosis.-Serum ferritin concentrations were all greatly increased in this condition with values ranging from 940 to $4,240 \mathrm{ng} / \mathrm{ml}$. The mean circulating ferritin concentration in this group was $2,646 \pm 494 \mathrm{ng} / \mathrm{ml}$ serum. There is a significant correlation between serum ferritin concentration and transferrin saturation in all patients with iron overload (Fig. 5) $(r=0.59, P<0.005)$. There is no difference in this respect between those patients with primary iron overload and those with primary refractory anaemia and secondary overload, suggesting that the relation is affected by impairment of erythropoiesis.

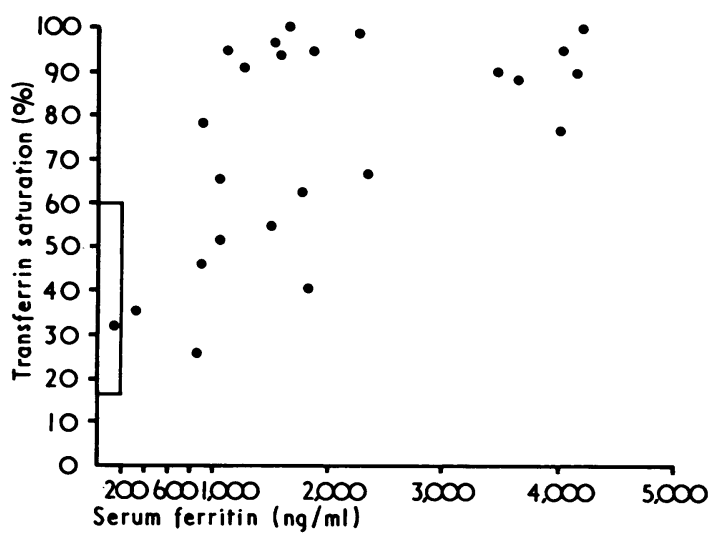

FIG. 5-Relation between serum ferritin concentration and transferrin saturation in patients with iron overload. Rectangular area shows normal limits of both parameters.

\section{Discussion}

The iron storage compound ferritin is a high molecular weight substance consisting of a protein shell with a molecular weight of 450,000 and a variable amount of hydrated ferric phosphate which forms a central core within the protein shell. Iron may constitute over $20 \%$ of the molecule, which may have a molecular weight as high as 900,000 . It has generally been regarded as an intracellular compound, but the present study shows that it is normally present in the circulation in concentrations between 10 and $200 \mathrm{ng} / \mathrm{ml}$. It has been suggested that circulating ferritin in the peripheral blood is derived from the iron stores present in reticuloendothelial cells. The well-defined range of serum concentrations implies a fairly steady influx, and this may result either from an active process of excretion by reticuloendothelial cells or by passive release as moribund cells reach the end of their normal lifespan.

Ferritin iron forms a reserve which can be drawn on when necessary for the synthesis of haemoglobin or other ironcontaining compounds. This is of particular importance in states of negative iron balance, and under these conditions storage iron is mobilized and eventually entirely depleted. The difference in serum ferritin concentration in males and females reflects the known difference in storage iron levels. Pritchard and Mason (1964) using the technique of repeated phlebotomy found the average stores in males to be $819 \mathrm{mg}$ while those of nulliparous females averaged only $254 \mathrm{mg}$. Weinfeld (1970) calculated the average non-haem iron content of liver to be $400 \mathrm{mg}$ for men and $130 \mathrm{mg}$ for menstruating women. The results of ferritin estimation in patients with iron deficiency and iron overload reinforce the suggestion that serum levels largely reflect iron stores. Patients with iron-deficiency anaemia have levels about one tenth those of normal subjects, and this may be related to the small amounts of non-haem iron inevitably associated with the process of erythropoiesis and haemoglobin catabolism.

The ability to sample and measure a segment of the ferritin pool in the body provides a method for the direct assessment of body iron stores. The histochemical estimation of stainable iron in bone marrow aspirates is at best only semi-quantitative and the same amount of stainable iron may reflect a wide range of actual available iron (Balcerzak et al., 1968). The measurement of urinary iron excretion after the administration of a chelating agent is an indirect method of assessing iron stores, and corrections for the proportion of non-excreted iron chelate are necessary. The present method offers some advantages over the chemical estimation of iron in marrow or liver biopsies (Weinfeld, 1970).

The three normal men who underwent repeated venesections had initial serum ferritin concentrations of 97,82 , and 22 $\mathrm{ng} / \mathrm{ml}$ respectively. The mobilizable iron stores in these three cases were calculated from the amount of haemoglobin iron removed before the serum ferritin concentration dropped to less than $10 \mathrm{ng} / \mathrm{ml}$. The amounts of storage iron were 1,300 , 1,400 , and $700 \mathrm{mg}$ respectively. Concentrations of circulating ferritin less than $10 \mathrm{ng} / \mathrm{ml}$ are associated with transferrin saturations less than $16 \%$, presumably because of impaired iron delivery to the plasma pool. This level, therefore, marks the lower limit of storage iron adequate to meet the demand of erythropoiesis. The upper limit of normal serum ferritin concentration is a little more difficult to define. In both men and women there is a skew distribution. Weinfeld (1970) found a skew distribution of storage iron concentration in liver and has shown that some subjects may have usually high levels. This is true of serum ferritin in the present group. No normal subject was found to have a serum ferritin concentration higher than $200 \mathrm{ng} / \mathrm{ml}$.

A.J. is in receipt of a grant from the Leukaemia Research Fund. We are indebted to Professor C. N. Hales and Dr. G. M Addison for their help and advice.

\section{References}

Addison, G. M., et al. (1972). Fournal of Clinical Pathology, 25, 326. Aungst, C. W. (1966). Foumal of Laboratory and Clinical Medicine, 67, 307

Balcerzak, S. P., Westerman, M. P., Heinle, E. W., and Taylor, F. H. (1968). Annals of Intermal Medicine, 68, 518.

Fielding, J. (1965). fournal of Clinical Pathology, 18, 88.

Pritchard, J., and Mason, R. A. (1964). Foumal of the American Medical Association, 190, 897 .

Reissman, K. R., and Dietrich, M. R. (1956). Fournal of Clinical Investigation, 35,588 .

Weinfeld, A. (1970). In Iron Stores in Iron Deficiency, Pathogenesis, Clinical Aspects and Therapy, ed. L. Hallberg, H. G. Harwerth, Clinical Aspects and Therapy, ed. L. Hall Young, D. S., and Hicks, J. M. (1965). Fournal of Clinical Pathology, 